\title{
Cell water content and lignification in maize regulated by rhizobacteria under salinity
}

\section{Yachana Jha}

N. V. Patel College of Pure \& Applied Sciences. S. P. University. V. V. Nagar. Anand (Gujarat). India. Email: yachanajha@ymail.com.

\begin{abstract}
Inoculation of plant growth promoting rhizobacteria (PGPR) Pseudomonas aeruginosa and Bacillus megaterium in maize plant under salinity stress was analyzed for its growth promotion efficacy and induction of physiological mechanism. In this study effect of these isolates were focused on the cellular level as with lignin deposition, cell wall lignin content and cell water status of maize under salinity. Maize plants get protected from the salinity induced injury by enhancing the plant growth, regulating relative water content, enhancing phenols, flavonoids as well as lignification of cell and antioxidant enzymes also. The study states that, PGPR helps in maize plant under salinity to increase the cell membrane stability, plays a significant action in the directive of cell permeability for the survival of plants. Nevertheless, the cell wall bounded peroxidase and phenylalanine ammonia-lyase (PAL) activity reduced with gradual increase soil in non-inoculated plants. So plants inoculated with selected root-associated bacteria has a positive response on cell content and water status in maize under salinity.
\end{abstract}

Keywords: Maize; Lignin; Cell membrane stability; Phenols; Flavonoids; Phenylalanine ammonia-lyase; Salinity.

\section{Introduction}

Maize (Zea mays L) is a most common incipient plant having broader compliance under diverse agricultural conditions. Maize can be magnificently cultivated in different types of soils extending from clay loam to loamy sand. It is a water stress sensitive crop, mainly extra soil moisture or low soil moisture due to soil salinity, being sensitive crop it is necessary to elude low land fields with improper drainage or field with high salt concentration. And salinity mainly influence on the plant biomass and it ultimately reduce crop production and quality (Yaycili and Alikamanoglu, 2012). Salinity consequences in a multiple types of biochemical and physiological changes in plants. So plants also have to advance themselves in a wide variety of physiological, biochemical and morphological modification that permit them to evade or abide stress and endure (Potters et al., 2006).

Salinity commonly effect the cell wall initially, and cell wall is composed by complex of cellulose, polysaccharides, proteins, fats and phenolic compound also at different stage of development. Among various cell wall phenolic compound lignin is one who is responsible for offering mechanical strength and toughness to the plant tissues and important for proper growth and development. Lignin not only provide physical stiffness, but also 
construct a physical barrier against different abiotic and biotic stresses (Hu et al., 2009).

The formation of secondary cell wall can be fortified by the integration of lignin. But lignification of plant tissues is a composite process involving numerous types of phenolic substrates and enzymes (Wang et al., 2013). To avoid cell wall damage of plants, when plants are exposed to water stress it occur naturally in early stage of development (Moura et al., 2010) and under stress cell wall lignin content and arrangement it changes (Cabane et al., 2012).

The phenylpropanoid pathway responsible for lignin synthesis in which L-phenylalanine is converted into trans-cinnamic acid by phenylalanine ammonia-lyase (PAL; EC 4.3.1.5.) enzyme. The PAL enzyme play positive role plant cell wall lignification and down-regulation of PAL enzyme effect the lignification process in plants (Ogras et al., 2000). Pandey et al. (2010) in a proteomic study, reported an enhanced PAL activity under drought stress in rice. Terzi et al. (2013) also reported that, PAL activity increased up to 16-fold and also effects the polyphenol oxidase activities, ionically wall-bound peroxidase and lignin content in grey-maranta (Ctenanthe setosa) when exposed to drought stress. Resent review highlighted that PAL activity induced in response to different stresses, like salinity, drought, heavy metals, physical injuries and infection by virus, bacteria, fungi etc. So PAL enzyme activate always induced when plant face any type of stress as defense response (Gao et al., 2008). PAL also has key role in the lignification and lignin act as an insulator for plant cell against different biotic and abiotic stress and also necessary for plant growth as provide mechanical strength (Moura et al., 2010). Any change in PAL and related enzyme as, peroxidase and polyphenol oxidase activities proportionally change the lignification under saline stresses.

The investigation was aim to observe the effect of plant growth promoting bacteria on growth, cell wall member, lignification and related enzymes taking place in maize cultivar under salinity.

\section{Materials and methods}

\section{Isolation, identification and inoculation of bacteria in maize}

The rhizosphere soil and root of halophytic weed plant Suaeda nudiflora wild mosque was used for the isolation of PGPR as per our publish method (Jha et al., 2014) and seeds of maize variety Pioneer 30 V92 were inoculated with isolates as per our published methods with some modification (Jha et al., 2011).

Maintenance of saline state and measurement of plant length and dry weight

The effect of these isolates were studied on maize at normal state and on $1.5 \%$ salinity. The saline condition was maintained at $1.5 \%$ salinity levels by adding $\left(15 \mathrm{~g} \mathrm{NaCl} \mathrm{L}^{-1}\right)$ saline solution to the pots as per our published method (Jha and Subramanian, 2013). To avoid osmotic shocks, $\mathrm{NaCl}$ concentration was stepwise enhanced for four successive days. The surplus water comes out of pot was collected in a plastic bag put underneath each pot and reapplied to the respective pot. All seedling were grown without any chemical supplement for 5 weeks in a in a greenhouse at the relative humidity $70 \%$ to $80 \%$ and 20 to $25{ }^{\circ} \mathrm{C}$ temperature. Plants were collected carefully with plant root from each and the shoots and roots length were measured. To determine dry weight plants sample were dried in an oven at $80^{\circ} \mathrm{C}$ for $72 \mathrm{~h}$.

\section{Relative water content}

The fully expanded leaves each from treatment was used for determination of leaf relative water content (RWC). Leaf discs of $10 \mathrm{~mm}$ diameter of each plant were expunged from the interveinal areas and twenty discs were pooled and their fresh weight was determined. To regain turgidity leaf discs were placed in distilled water in Petri dishes for $4 \mathrm{~h}$ and re-weighed for total weight. The dry weight were determined by 
drying the leaf discs at $80{ }^{\circ} \mathrm{C}$ for $24 \mathrm{~h}$. Complete hydration of the leaf discs occurred within 4 h. RWC was defined as follows:

$$
\text { RWC }(\%)=((F W-D W) /(T W-D W)) \times 100
$$

\section{leakage)}

Cell membrane stability (solute

Solute Leakage of the leaves was determined by taking $500 \mathrm{mg}$ of leaves from each treatment, using a conductivity meter (DIGICOND IV, Buenos Aires. Argentina), CMS was determined according to the following equation:

$$
\mathrm{CMS}=((1-(\mathrm{T} 1 / \mathrm{T} 2)) /(1-(\mathrm{C} 1 / \mathrm{C} 2))) \times 100
$$

Where $\mathrm{C}$ and $\mathrm{T}$ refer to the conductivity of control and treated sample. $\mathrm{C} 1$ and $\mathrm{T} 1$ represent the electrolyte leakage $\left(\mathrm{dS} \mathrm{m} \mathrm{m}^{-1}\right.$ ) after incubating at $25{ }^{\circ} \mathrm{C}$ for $4 \mathrm{~h}$, and $\mathrm{C} 2$ and $\mathrm{T} 2$ represent the total electrolyte concentration at room temperature measured after heating in boiling water for $60 \mathrm{~min}$. $\mathrm{T} 1$ and $\mathrm{T} 2$ correspond to the first and second solution conductivity of treated samples, and C1 and $\mathrm{C} 2$ are the respective values for the controls.

\section{Determination of phenols, flavonoids, lignin and lignin monomers \\ Ten plants of each treatment were} collected, and three replicates were performed, for each evaluation. Shoots were separated from the root, washed, and placed in a forced air circulation oven at $65^{\circ} \mathrm{C}$ for 7 days, until a constant mass was reached. The shoots were then ground using liquid nitrogen and stored at $\pm 4^{\circ} \mathrm{C}$.

The total lignin and lignin monomers were determined from homogenized sample in $50 \mathrm{mM}$ sodium phosphate buffer, $\mathrm{pH} 7.0$, purified in $1 \%$ Triton X-100, $1 \mathrm{M} \mathrm{NaCl,} \mathrm{acetone}$ centrifuged for $15 \mathrm{~min}$, according to Kováčik and Klejdus (2008). The pellet was dried and considered as the protein freed from cell walls. Lignin and lignin monomers were quantified using thioglycolic acid and alkaline nitrobenzene peroxidation, respectively (Van Der Rest et al., 2006).
For total phenols and flavonoids, one gram of leaf was extracted in $20 \mathrm{~mL}$ methanol $(80: 20 \mathrm{v} / \mathrm{v})$ for $15 \mathrm{~min}$, and the extract was re-suspended in $20 \mathrm{~mL}$ of $1 \%$ Triton X-100. The extract was used for the determination of the total phenol content using a spectrophotometer (absorbance 735 $\mathrm{nm}$ ). A standard curve was obtained using gallic acid. Flavonoid contents were determined from extracts in aluminum chloride by a colorimetric assay (735 nm) (Abou Zid and Elsherbeiny, 2008).

\section{Lignin histochemical staining}

Transverse sections were made using a vibratome from internodes of plants grown under salinity. Phloroglucinol staining was performed according to standard protocols. Sections were examined under an image analyzer microscope (Carl Zeiss).

\section{PAL activity}

Three hundred $\mathrm{mg}$ of leaves samples from each treatment were homogenized in $6.5 \mathrm{~mL}$ Tris-HCl buffer at $\mathrm{pH} \quad 8.8$ containing $15 \mathrm{mM}$ of $\beta$ mercaptoethanol and centrifuged at $12,000 \mathrm{rpm}$ for $30 \mathrm{~min}$ to obtain the supernatant used for enzyme activity assay (Wang et al., 2012). $1 \mathrm{~mL}$ of the extraction buffer, $0.5 \mathrm{~mL}$ of $10 \mathrm{mM}$ L-phenylalanine (ME - 1.07256), $0.35 \mathrm{~mL}$ of double distilled water and $0.15 \mathrm{~mL}$ of enzyme extract were incubated for $1 \mathrm{~h}$ at $37^{\circ} \mathrm{C}$ in a water bath and the reaction was stopped by adding 0.5 
$\mathrm{mL}$ of $6 \mathrm{M} \mathrm{HCl}$. The product was extracted with $15 \mathrm{~mL}$ ethylacetate, followed by evaporation to remove the extracting solvent. The solid residue was suspended in $3 \mathrm{~mL}$ of $0.05 \mathrm{M} \mathrm{NaOH}$ and the amount of cinnamic acid was quantified spectrophotometrically at $290 \mathrm{~nm}$.

\section{Cell wall peroxidase activity}

Peroxidases were extracted and measured in two fractions. The reaction mixture consisted of $0.018 \mathrm{mM}$ of syringaldazine buffer (Sigma), $0.05 \mathrm{mM}$ of $\mathrm{H}_{2} \mathrm{O}_{2}$ buffer, $60 \mathrm{mM}$ phosphate sodium buffer ( $\mathrm{pH} \mathrm{6)}$ and the enzyme extract. The activities of ionically and covalently bound peroxidases were expressed as the increase in absorbance at $530 \mathrm{~nm} \mathrm{mg}^{-1}$ protein with the extinction coefficient of $27 \mathrm{mM}^{-1} \mathrm{~cm}^{-1}$.

\section{Statistical analysis}

Each pot was considered as replicate and all of the treatments were repeated three times. A two-way analysis of variance (ANOVA) was performed using STATISTICA program. The means and calculated standard errors are reported. The significance was tested at 5\% level.

\section{Results}

\section{bacteria}

Characteristics of isolated

The two bacteria were isolated from the plant Suaeda nudiflora for this study. The plant Suaeda nudiflora were grown in soil possessing the following physio-chemical properties; pH 6.58, electrical conductivity $1480 \mu \mathrm{S} / \mathrm{cm}$, salinity $8.6 \%$, nitrate $112.5 \mathrm{mg} \mathrm{kg}^{-1}$, chloride $128 \mathrm{mg} \mathrm{kg} \mathrm{kg}^{-1}$, sulphate $155 \mathrm{mg} \mathrm{kg}$, ammonia nitrogen $23.3 \mathrm{mg} \mathrm{kg}^{-1}$, CEC: 3 cmol, organic carbon: $5500 \mathrm{mg} \mathrm{kg}^{-1}$. Out of two isolates, one was Gram positive endospore forming bacteria of size $2.6 \times 1.2$ $\mu \mathrm{m}$ and was non-capsulated, motile by perichate flagella. The other was Gram negative short rods, motile having polar flagella and non-sporulating. Molecular analysis of the isolates was done by $16 \mathrm{~S}$ rDNA analysis. Nucleotides homology and phylogenetic analysis of the isolates identified it as Pseudomonas aeruginosa
(GenBank Accession Number: JQ790515) and Bacillus megaterium (GeneBank Accession Number: JQ790514).

\section{dry weight \\ Measurement of plant length and}

The effect of isolated bacteria on maize plants showed significantly enhanced plant height, root length, and dry weight. Plant inoculated with $B$. megaterium showed 20\% enhanced plant height, 15\% longer root length and 11\% increased dry weight, while $P$. aeruginosa treated plants showed 30\% more dry weight, 25\% higher plant height and 46\% longer root length compared to non-inoculated control as shown in Table 1. The plant inoculated with both $B$. megaterium and $P$. aeruginosa had $20 \%$ higher plant height, 20\% longer root length and $5 \%$ greater dry weight compared to non-inoculated control. Salinity adversely affects all the growth parameters in spite of PGPR treatment. Maize plants inoculated with PGPR under salinity have increased height by $14 \%-30 \%$, shoot weight by $0.5 \%-40 \%$, root weight by $3.2 \%-21 \%$, and total fresh weight by $39 \%-54 \%$ under saline stress.

Determination of RWC, CMS, phenols, flavonoids, lignin and lignin monomers

Exposure to salinity greatly influences plant water potential and cell membrane stability. The low leaf water status was recorded in non-inoculated control plants compared to the PGPR application during normal growth conditions. The RWC (relative water content) in inoculated plants, increased by $17 \%$ and it decreased by $20 \%$ in plant inoculated with both PGPR under normal state. While salinity decreased the RWC by $40 \%$ in control and only by $20 \%$ in inoculated plants. However, the noninoculated control plants had significantly lower water potential as compared to the inoculated plants after induction of salinity stress.

Cell membrane stability significantly increased in inoculated plants, both in normal as well as under salinity. Inoculation with PGPR enhanced the CMS 
by $25 \%$ in non-saline state and $27 \%$ under salinity compared to non-inoculated control plants. CMS decreased by $40 \%$ in control non-inoculated plants.

Phenol and flavonoid significantly increased in inoculated plants, both under non-saline as well as under salinity. Salinity also enhanced the phenol and flavonoid content in maize. Plants inoculated with PGPR and salinity showed a nearly same increase in phenols. Flavonoid content gets nearly double in the maize plant due to PGPR under salinity.

Table 1. Effect of PGPR strains on plant growth promoting activity in maize plant.

\begin{tabular}{|c|c|c|c|c|c|c|c|c|c|}
\hline \multirow{2}{*}{ Treatment } & \multirow{2}{*}{$\begin{array}{l}\text { Shoot } \\
\text { length } \\
(\mathrm{cm})\end{array}$} & \multirow{2}{*}{$\begin{array}{l}\text { Root } \\
\text { length } \\
(\mathrm{cm})\end{array}$} & \multirow{2}{*}{$\begin{array}{c}\text { Plant } \\
\text { height } \\
(\mathrm{cm})\end{array}$} & \multicolumn{2}{|c|}{ Shoot weight (g) } & \multicolumn{2}{|c|}{ Root weight (g) } & \multicolumn{2}{|c|}{ Total biomass (g) } \\
\hline & & & & $\begin{array}{l}\text { Fresh } \\
\text { weight }\end{array}$ & $\begin{array}{c}\text { Dry } \\
\text { weight }\end{array}$ & $\begin{array}{l}\text { Fresh } \\
\text { weight }\end{array}$ & $\begin{array}{c}\text { Dry } \\
\text { weight }\end{array}$ & $\begin{array}{l}\text { Fresh } \\
\text { weight }\end{array}$ & $\begin{array}{c}\text { Dry } \\
\text { weight }\end{array}$ \\
\hline \multicolumn{10}{|c|}{$1.5 \%$ salinity } \\
\hline Control & $14.50^{\mathrm{d}}$ & $15.00^{\mathrm{d}}$ & $29.50^{\mathrm{d}}$ & $0.960^{\mathrm{d}}$ & $0.190^{\mathrm{d}}$ & $0.660^{d}$ & $0.105^{\mathrm{d}}$ & $1.026^{\mathrm{d}}$ & $0.295^{\mathrm{d}}$ \\
\hline $\begin{array}{l}\text { Control + } \\
\text { B. megaterium }\end{array}$ & $18.66^{\mathrm{bc}}$ & $19.00^{\mathrm{abc}}$ & $34.66^{b c}$ & $1.270^{\circ}$ & $0.260^{b e}$ & $0.720^{b c}$ & $0.120^{b c}$ & $1.690^{\mathrm{c}}$ & $0.380^{\mathrm{be}}$ \\
\hline $\begin{array}{l}\text { Control }+ \\
P . \text { aeruginosa }\end{array}$ & $19.00^{b}$ & $21.50^{\mathrm{ab}}$ & $39.50^{\mathrm{ab}}$ & $1.595^{\mathrm{b}}$ & $0.285^{b}$ & $0.775^{b}$ & $0.145^{b}$ & $2.270^{\mathrm{a}}$ & $0.340^{b}$ \\
\hline $\begin{array}{l}\text { Control }+ \\
\text { B. megaterium }+ \\
P . \text { aeruginosa } \\
\end{array}$ & $20.16^{\mathrm{a}}$ & $23.00^{\mathrm{a}}$ & $42.16^{\mathrm{a}}$ & $1.995^{\mathrm{a}}$ & $0.325^{\mathrm{a}}$ & $0.840^{\mathrm{a}}$ & $0.155^{\mathrm{a}}$ & $2.240^{\mathrm{ab}}$ & $0.370^{\mathrm{a}}$ \\
\hline \multicolumn{10}{|c|}{$0 \%$ salinity } \\
\hline Control & $19.02^{d}$ & $17.21^{\mathrm{d}}$ & $34.17^{\mathrm{d}}$ & $1.124^{\mathrm{d}}$ & $0.421^{\mathrm{d}}$ & $0.863^{\mathrm{d}}$ & $0.238^{\mathrm{ed}}$ & $1.215^{\mathrm{d}}$ & $0.334^{d}$ \\
\hline $\begin{array}{l}\text { Control + } \\
\text { B.megaterium }\end{array}$ & $28.21^{\mathrm{c}}$ & $26.17^{b c}$ & $47.24^{\mathrm{be}}$ & $2.112^{b e}$ & $0.511^{\mathrm{e}}$ & $0.912^{\mathrm{c}}$ & $0.246^{\mathrm{be}}$ & $2.807^{\mathrm{e}}$ & $0.498^{\mathrm{c}}$ \\
\hline $\begin{array}{l}\text { Control + } \\
\text { P.aeruginosa }\end{array}$ & $32.11^{b}$ & $31.26^{\mathrm{ab}}$ & $51.12^{a b}$ & $2.433^{\mathrm{b}}$ & $0.653^{b}$ & $0.986^{b}$ & $0.257^{\mathrm{ab}}$ & $3.789^{\mathrm{ab}}$ & $0.579^{b}$ \\
\hline $\begin{array}{l}\text { Control + } \\
\text { B.megaterium + } \\
\text { P.aeruginosa }\end{array}$ & $39.41^{\mathrm{a}}$ & $35.14^{\mathrm{a}}$ & $54.32^{\mathrm{a}}$ & $3.215^{\mathrm{a}}$ & $0.746^{\mathrm{a}}$ & $1.121^{\mathrm{a}}$ & $0.298^{\mathrm{a}}$ & $3.982^{\mathrm{a}}$ & $0.691^{\mathrm{a}}$ \\
\hline
\end{tabular}

Values are mean of three replications. Means within columns sharing the same letters are not significantly different $(\mathrm{P} \leq 0.05$; LSD test).

Lignin and lignin monomer increase in inoculated plants both, in normal and salinity state. Salinity caused a significant increase $(\mathrm{P}<0.05)$ in lignin content in maize plant. The increase in lignin deposition was evident as the salinity increased as shown in Table 2.

\section{Lignin histochemical study}

Transverse sections were prepared from all treatment of maize root. The sections were stained with phloroglucinol for xylem vessels, sclerenchyma cells surrounding the vascular bundles. These tissues situated directly under the epidermis stained with phloroglucinol, confirming that all these cells are lignified under salinity as well as due to PGPR, and both the isolates have a similar effect on lignification as of salinity (Figure 1).

\section{(PAL) activity}

Phenylalanine ammonia-lyase

The PAL activity of the maize increased by inoculation of PGPR and under salinity as shown in Figure 2. The PAL activity enhanced by $21 \%-27 \%$ due to inoculation with PGPR in the normal state and salinity results in enhanced PAL activity by $57 \%-59 \%$. 
Table 2. Effect of PGPR strains on RWC, cell membrane stability, phenols, flavonoid, lignin and lignin monomer in maize plant.

\begin{tabular}{|c|c|c|c|c|c|c|c|}
\hline $\begin{array}{c}\% \\
\text { Salinity }\end{array}$ & Treatment & RWC \% & $\begin{array}{c}\text { Cell } \\
\text { membrane } \\
\text { stability }\end{array}$ & Phenols & Flavonoids & Lignin & $\begin{array}{c}\text { Lignin } \\
\text { monomers }\end{array}$ \\
\hline $0.0 \%$ & No inoculation & $140.2^{\mathrm{d}}$ & $132.4^{\mathrm{ed}}$ & $0.83^{\mathrm{ed}}$ & $8.76^{\text {ed }}$ & $1.32^{\mathrm{ed}}$ & $0.8^{\mathrm{d}}$ \\
\hline \multirow{2}{*}{$\mathrm{NaCl}$} & Maize with $B$. megaterium & $153^{\mathrm{be}}$ & $154.1^{\mathrm{bc}}$ & $0.91^{\text {be }}$ & $8.92^{\circ}$ & $1.49^{\mathrm{e}}$ & $1.02^{\mathrm{e}}$ \\
\hline & Maize with $P$. aeruginosa & $164.7^{\mathrm{ab}}$ & $167.7^{b}$ & $0.98^{\mathrm{ab}}$ & $9.21^{\mathrm{ab}}$ & $1.53^{\mathrm{b}}$ & $1.23^{b}$ \\
\hline \multirow[t]{2}{*}{ Control } & $\begin{array}{l}\text { Maize with } B \text {. megaterium }+ \\
\text { P. aeruginosa }\end{array}$ & $169.3^{\mathrm{a}}$ & $176.3^{\mathrm{a}}$ & $1.12^{\mathrm{a}}$ & $9.49^{\mathrm{a}}$ & $1.59^{\mathrm{a}}$ & $1.32^{\mathrm{a}}$ \\
\hline & No inoculation & $83.1^{\mathrm{d}}$ & $78.1^{\text {cd }}$ & $0.91^{\mathrm{ed}}$ & $9.12^{\text {cd }}$ & $1.41^{\mathrm{d}}$ & $1.09^{\mathrm{cd}}$ \\
\hline $1.5 \%$ & Maize with B. megaterium & $96.2^{\mathrm{be}}$ & $89.4^{\mathrm{be}}$ & $0.97^{\mathrm{c}}$ & $9.76^{\mathrm{be}}$ & $1.56^{\mathrm{be}}$ & $1.11^{\mathrm{e}}$ \\
\hline \multirow[t]{2}{*}{$\mathrm{NaCl}$} & Maize with $P$. aeruginosa & $99.7^{\mathrm{b}}$ & $97.7^{\mathrm{ab}}$ & $1.23^{\mathrm{b}}$ & $10.2^{\mathrm{ab}}$ & $1.58^{\mathrm{b}}$ & $1.29^{\mathrm{ab}}$ \\
\hline & $\begin{array}{l}\text { Maize with } B \text {. megaterium }+ \\
P \text {. aeruginosa }\end{array}$ & $104.1^{\mathrm{a}}$ & $96.6^{\mathrm{a}}$ & $1.31^{\mathrm{a}}$ & $10.9^{\mathrm{a}}$ & $1.61^{\mathrm{a}}$ & $1.31^{\mathrm{a}}$ \\
\hline
\end{tabular}

Values are mean of three replications. Means within columns sharing the same letters are not significantly different $(\mathrm{P} \leq 0.05$; LSD test).

A

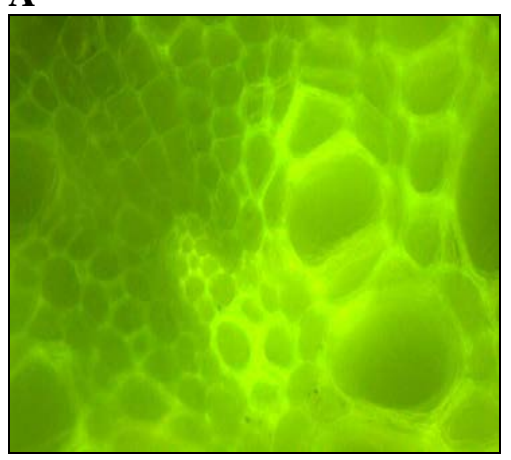

B

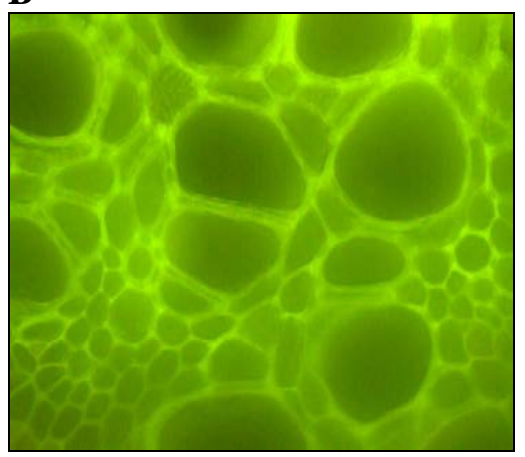

C

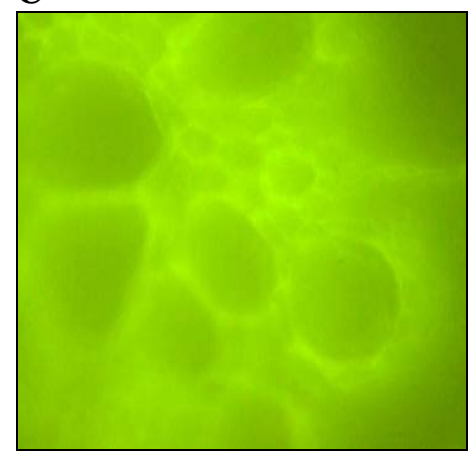

Figure 1. Effect of PGPR on lignin in maize cell at $1.5 \%$ salinity $(n=5)$. Where. $A=$ Control; $\mathrm{B}=$ Inoculated with Pseudomonas aeruginosa; and C = Bacillus megaterium.

\section{activity}

\section{Cell wall bound peroxidase}

The activity of cell wall peroxidase during developmental stages are shown in Figure $3 \mathrm{a}$ and $3 \mathrm{~b}$. Both ionically and covalently bound cell wall peroxidases were present in the cell walls of maize. The activity of wall bound peroxidases increased significantly in all treatment under salt stress. Inoculation of PGPR enhanced the ionically bounded lignin both in normal as well as under stress. The ionically bounded lignin increased by $8.3 \%$ in normal condition and 20\% under salinity, while covalently bound peroxidase increased by $8.7 \%-14 \%$ in normal and salinity, respectively. 


\section{PAL Activity}

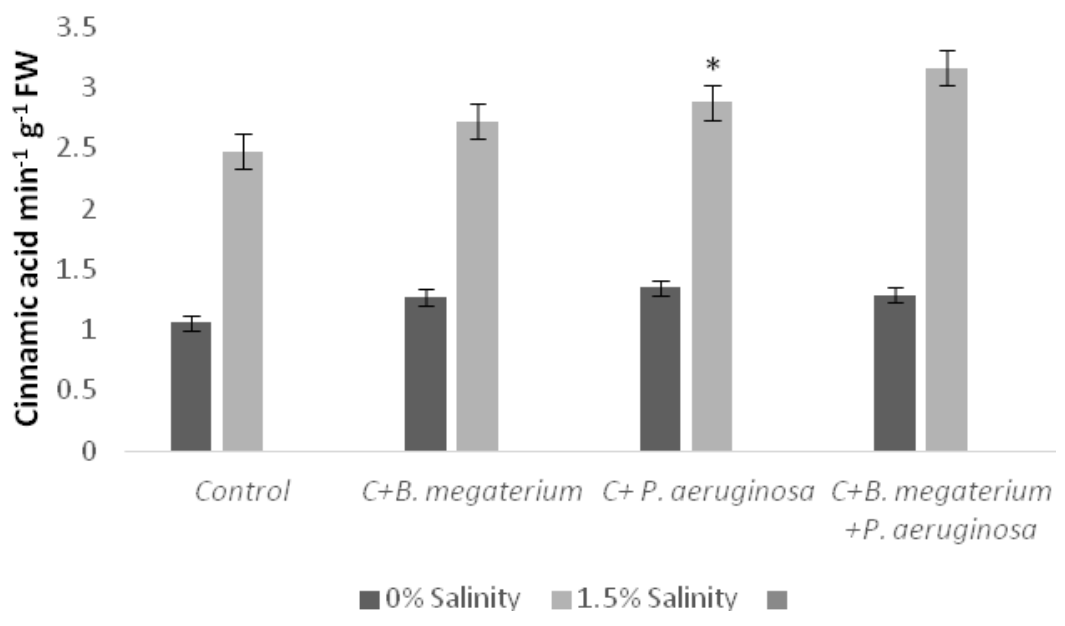

Figure 2. Effect of PGPR on PAL activity in maize cell at $1.5 \%$ salinity $(n=5)$.

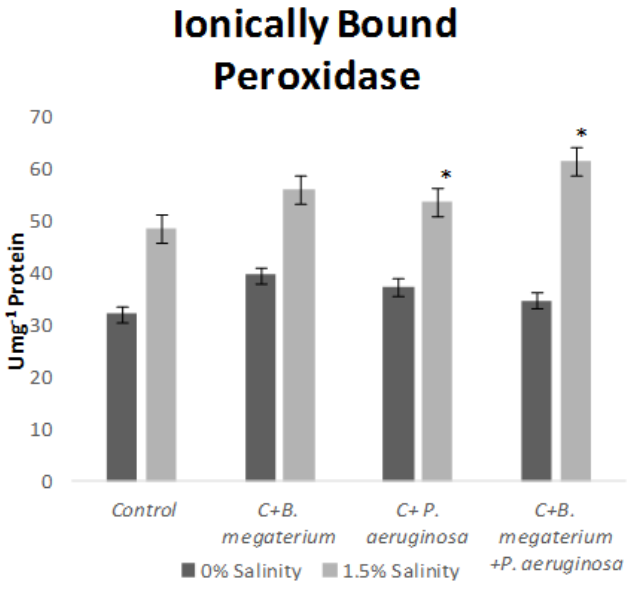

a $\mathrm{b}$

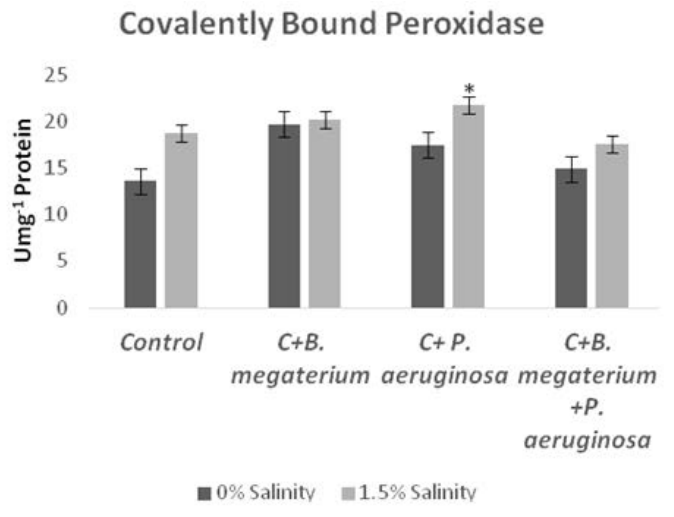

Figure 3. Effect of PGPR on ironically and covalently bound peroxidase in maize cell at $1.5 \%$ salinity $(n=5)$.

\section{Discussion}

Plants growing on land experience a multitude of environmental stresses. These stresses include drought, salinity, water logging, extremes of temperature, radiation, mineral deficiency, etc. Although appraisal of the effects of all different stresses on plants is important, in view of the existing literature more emphasis of the researchers can be observed on salinity than on other stresses. This is due to the fact that vast area of the available land on the globe comprising a large number of countries affected by salinity. Plants grow in agricultural soil is influenced by many environmental factors. While using physical and chemical approaches to managing the soil environment to improve crop yield, the application of microbial products for this purpose is less common. Beneficial microorganisms can be an important component for management practices to achieve the yield. The results obtain from 
pot study showed that salinity adversely affects the growth of maize, but plants inoculated with individual bacterial isolates and their mixture have enhanced plant height, root length, and dry weight. Among the two isolates, Pseudomonas aeruginosa was found to be more effective than Bacillus megaterium and the mixture of both showed the best growth response of maize plants.

Water status is the main factor affecting the plants' growth and development. Decreasing external water potential produces a net accumulation of solutes in cells, which lowers the cell osmotic potential necessary for maintaining the turgor pressure (Suárez and Medina, 2008). An interesting observation of this study was that plants inoculated with PGPR in normal as well as under salinity have greater RWC and cell membrane stability which is accordance with Sandhya et al. (2010). Shaharoona et al. (2006), reported that the inoculation with PGPR increased RWC under normal as well as under stress conditions as compared to the un-inoculated control. Non-inoculated plants have decreased RWC and cell membrane stability with increased salinity. Membranes are main loci affected under water stress conditions.

Phenolics are compounds possessing one or more aromatic rings with one or more hydroxyl groups. They are broadly distributed in the plant kingdom and are the most abundant secondary metabolites of plants. Like phenolic acids, flavonoids are also secondary metabolites of plants with polyphenolic structure and are synthesized by the polypropanoid pathway as the startup component is phenylalanine molecule. This study showed that inoculation of PGPR alone is sufficient to increase the phenolic and flavonoid content in maize plant in normal state and under salinity no further increase has been observed. Ghasemzadeh et al. (2010), showed that the synthesis of phenolics and flavonoids in ginger can be increased and affected by under abiotic stress.

Plants rely on their cell walls to provide shape and strength to the cells, to glue cells together and to give rigidity to the whole plant. Lignin in crops interacts with abiotic stresses in two ways; (i) many abiotic stresses influence lignin biosynthesis and therefore affect the lignin content of crops and (ii) lignification of crop tissues affects plant fitness and can confer tolerance to abiotic stresses (Pedersen et al., 2005). In this study, both lignin and lignin monomer increased in inoculated plants, both in normal and salinity state. Recently, Wang et al. (2012), has reported that transgenic rice line deposited enhanced levels of lignin when exposed to salt treatment are more tolerant than its wild type. Martinez et al. (2004) reported that the highest accumulation of lignin monomers was observed in the plants treated with $P$. aeruginosa. Vincent et al. (2005), was found that a water deficit decreased the level of lignifying enzymes and consequently the lignin level in maize leaves. The beneficial effects of lignification were explained by anatomical changes that facilitate water flow and maintain the structural integrity of the xylem vessels during salt stress. In the present study, the histochemical analysis didn't show any significant difference in lignin deposition among inoculated and non-inoculated maize under salinity. However, Moura et al. (2010), has reported that abiotic and biotic stress tends to affect the lignification of crops. Such reaction leads to histological changes, such as the formation of papillae, lignification, deposition of callose, and thickening of the cell wall due to deposition of phenols and substances similar to hydrogen peroxide (Rubin, 2008).

PAL is the rate-limiting enzyme for secondary metabolites, and also plays an important role in plant stress tolerance. Phenylalanine ammonia-lyase (PAL) is a key intermediate at the crossroads of phenolics and lignin synthetic pathways. PAL, which catalyzes the deamination of phenylalanine to trans-cinnamate, was shown to be regulated upon stress exposure. In the present study, both the bacterial isolate and salinity enhanced PAL activity, is supported by Pandey et al. (2010), who reported an increased level of PAL following drought stress in rice. 
Cell wall peroxidases are involved in growth modifications by affecting cell wall via biochemical processes. Crosslinkages between cell wall compounds are mediated by these enzymes. In the present study, both the bacterial isolate and salinity showed the enhanced cell wall peroxidase activity. Several studies have investigated the roles of cell wall peroxidases and their reverse relation to cell growth by stiffening processes. It is known that cell wall peroxidases also influence growth and development of plant by limiting certain growth related reactions through collaboration with phenolic compounds, resulted in reduce wall extensibility. Enhanced PAL activity with subsequent effects on polyphenol oxidase, lignin content, ionic and cell wall-bound peroxidase activities is also supported by Terzi et al. (2013). Our finding suggest that inoculation of maize with such isolates could provide salt tolerant ability of plants and serves as a useful tool for alleviating salinity stress.

\section{Conclusion}

The interaction of PGPR and maize plants result in the induction of series of morphological, anatomical and enzymatic changes in plants. Such induction capable the plant to develop the ability to overcome abiotic stress including increase in PAL activity, phenolic content lignification and finally in cell wall component. It speculates through our studies that induction of such stress-related enzymes is irrespective of stress and prior to any abiotic stress, merely by inoculation with PGPR bacteria.

\section{References}

Abou Zid, S. F.; Elsherbeiny, G. M. Increase in flavonoids content in red onion peel by mechanical shredding. J. Med. Plant. Res., v. 2, p. 258-260, 2008. Available from: $<$ http://www.academicjournals.org/article/articl e1380382031_AbouZid and Elsherbeiny.pdf>. Accessed on: Mar. 15, 2017.

Cabane, M.; Afif, D.; Hawkins, S. Lignins and abiotic stresses. In: Jouanin, L.; Lapierre, C. (Ed.). Lignins biosynthesis, biodegradation and bioengineering. London: Academic Press, 2012. (Advances in Botanical Research). v. 61, p. 219-262. http://doi.org/10.1016/B978-0-12416023-1.00007-0

Gao, S.; Ouyang, C.; Wang, S.; Xu, Y.; Tang, L.; Chen, F. Effects of salt stress on growth, antioxidant enzyme and phenylalanine ammonia-lyase activities in Jatropha curcas L seedlings. Plant Soil Environ., v. 54, p. 374-381, 2008. Available from: $<$ http://www.agriculturejournals.cz/publicFiles/ 02069.pdf>. Accessed on: Mar. 15, 2017.

Ghasemzadeh, A.; Jaafar, H. Z. E.; Rahmat, A. Elevated carbon dioxide increases contents of flavonoids and phenolic compounds, and antioxidant activities in Malaysian young ginger (Zingiber officinale Roscoe.) varieties. Molecules, v. 15, no. 11, p. 7451-7466, 2010. http://dx.doi.org/10.3390/molecules15117907

Hu, Y.; Li, W.C.; Xu, Y.Q.; Li, G.Y.; Lia, Y.; Fu, F.I. Differential expression of candidate genes for lignin biosynthesis under drought stress in maize leaves. J. Appl. Genet., v. 50, No. 3, p. 213-223, 2009. https://dx.doi.org/10.1007/BF03195675

Jha, Y.; Subramanian, R. B.; Patel, S. Combination of endophytic and rhizospheric plant growth promoting rhizobacteria in Oryza sativa shows higher accumulation of osmoprotectant against saline stress. Acta Physiol. Plant., v. 33, No. 3, p. 797-802, 2011. https://dx.doi.org/10.1007/s11738-010-0604-9

Jha, Y.; Subramanian, R. B. Paddy physiology and enzymes level is regulated by rhizobacteria under saline stress. J. Appl. Bot. Food Qual., v. 85, p. 168-173, 2013. Available from: $<$ https://ojs.openagrar.de/index.php/JABFQ/arti cle/view/2317/2662>. Accessed on: Mar. 15, 2017.

Jha, Y.; Subramanian, R. B.; Jethwa, R.; Patel, N. Identification of plant growth promoting rhizobacteria from Suaeda nudiflora plant and its effect on maize. Indian J. Plant Prot., v. 42, No. 4, p. 422-429, 2014.

Jha, Y.; Subramanian, R. B. Rhizobacteria enhance oil content and physiological status of Hyptis suaveolens under salinity stress. Rhizosphere, $\quad$ v. 1, p. 33-35, 2016. http://doi.org/10.1016/j.rhisph.2016.07.006

Kováčik, J.; Klejdus, B. Dynamics of phenolic acids and lignin accumulation in metal-treated Matricaria chamomilla roots. Plant Cell Rep., v. 27, No. 3, p. 605-615, 2008. https://dx.doi.org/10.1007/s00299-007-0490-9

Martinez, D.; Larrondo, L. F.; Putnam, N. Genome sequence of the lignocellulose 
degrading fungus Phanerochaete chrysosporium strain RP78. Nature Biotechnol., v. 22, No. 6, p. 695-700, 2004. https://dx.doi.org/10.1038/nbt967

Moura, J. C. M. S.; Bonine, C. A. V.; Viana, J. O. F.; Dornelas, M. C.; Mazzafera, P. Abiotic and biotic stresses and changes in the lignin content and composition in plants. J. Integr. Plant Biol., v. 52, no. 4, p. 360-376, 2010. https://dx.doi.org/10.1111/j.17447909.2010.00892.x

Oğraş, T. T.; Kazan, K.; Gözükirmizi, N. Reduction of lignin in tobacco through the expression of an antisence caffeic acid omethyltransferase. Turk J. Bot., v. 24, no. 4, p. 221-226, 2000. Available from: $<$ http://journals.tubitak.gov.tr/botany/issues/bot00-24-4/bot-24-4-2-9907-9.pdf>. Accessed on: Mar. 15, 2017.

Pandey, A.; Rajamani, U.; Verma, J.; Subba, P.; Chakraborty, N.; Datta, A.; Chakraborty, S.; Chakraborty, N. Identification of extracellular matrix proteins of rice (Oryza sativa L.) involved in dehydration-responsive network: a proteomic approach. J. Proteome Res., v. 9, p. 3443-3464, 2010. https://dx.doi.org/10.1021/pr901098p

Pedersen, J. F.; Vogel, K. P.; Funnell, D. L. Impact of reduced lignin on plant fitness. Crop Sci., v. $45, \quad$ p. $812-819, \quad 2005$. https://dx.doi.org/10.2135/cropsci2004.0155

Potters, G.; Jansen, M. A. K.; Guisez, Y.; Pasternak, T. Stress drives plant cells to take the road towards embryogenesis. In: Teixeira da Silva, J. A. (ed.). Floriculture, ornamental and plant biotechnology, advances and topical issues. London, UK: Global Science Books, 2006. v. 2. p. 289-294.

Rubin, E. M. Genomics of cellulosic biofuels. Nature, v. 454, p. 841-845, 2008. https://dx.doi.org/10.1038/nature07190

Sandhya, V.; Ali, S. K. Z.; Grover, M.; Reddy, G.; Venkateswarlu, B. Effect of plant growth promoting Pseudomonas spp. on compatible solutes, antioxidant status and plant growth of maize under drought stress. Plant Growth Regul., $\quad$ v. 62, $\quad$ p. 21-30, 2010. https://dx.doi.org/10.1007/s10725-010-9479-4
Shaharoona, B.; Arshad, M.; Zahir, Z. A. Effect of plant growth promoting rhizobacteria containing ACC-deaminase on maize (Zea mays L.) growth under axenic conditions and on nodulation in mung bean (Vigna radiata L.). Lett. Appl. Microbiol., v. 42, p. 155-159, 2006. https://doi.org/10.1111/j.1472-765X.2005.01827.x

Suárez, N.; Medina, E. Salinity effects on leaf ion composition and salt secretion rate in Avicennia germinans (L.) L. Braz. J. Plant Physiol., v. 20, no. 2, p. 131-140, 2008. http://dx.doi.org/10.1590/S167704202008000200005

Terzi, R.; Güler, N. S.; Kutlu Çalişkan, N.; Kadioğlu, A. Lignification response for rolled leaves of Ctenanthe setosa under long-term drought stress. Turk. J. Biol., v. 37, p. 614-619, 2013. https://dx.doi.org/10.3906/biy-1210-27

Van Der Rest, B.; Danoun, S.; Boudet, A.-M.; Rochange, S. F. Down-regulation of cinnamoylCoA reductase in tomato (Solanum lycopersicum L.) induces dramatic changes in soluble phenolic pools. J. Exp. Bot., v. 57, No. 6, $\quad$ p. 1399-1411, 2006. https://doi.org/10.1093/jxb/erj120

Vincent, D.; Lapierre, C.; Pollet, B.; Cornic, G.; Negroni, L.; Zivy, M. Water deficits affect caffeate O-methyltransferase, lignification, and related enzymes in maize leaves: a proteomic investigation. Plant. Physiol., v. 137, No. 3, p. 949-960, 2005. https://doi.org/10.1104/pp.104.050815

Wang, H. M.; Zhou, L.; Fu, Y. P. Expression of an apoplast localized BURP-domain protein from soybean (GmRD22) enhances tolerance towards abiotic stress. Plant Cell Environ., v. 35, p. 1932-1947, 2012. https://dx.doi.org/10.1111/j.13653040.2012.02526.x

Wang, Y.; Chantreau, M.; Sibout, R.; Hawkins, S. Plant cell wall lignification and monolignol metabolism. Front. Plant Sci., v. 4, article 220, 14 p., 2013. https://dx.doi.org/10.3389/fpls.2013.00220

Yaycili, O.; Alikamanoğlu, S. Induction of salttolerant potato (Solanum tuberosum L.) mutants with gamma irradiation and characterization of genetic variations via RAPD-PCR analysis. Turk J. Biol., v. 36, p. 405-412, 2012. http://dx.doi.org/10.3906/biy-1110-14 